




\section{Using E-portiolio to Develop EFL Fluency Skills among Secondary School Students}

\section{By}

\section{Marwa Elsayed Ahmed Ibrahim}

Researcher, Faculty of Education, Benha University.

\section{Dr. Eman Mohamed Abd El-Hack}

Professor of EFL Curriculum \& Instruction and Dean of Faculty of Education, Benha University

\section{Dr. Mona Salem Zaza}

Professor of EFL Curriculum \& Instruction and Vice Dean of Environmental Affairs and Community Service Faculty of Education, Benha University

\section{Abstract}

The present study was an attempt to investigate the effectiveness of using e-portfolio for developing fluency skills among first year secondary stage students. The design of the study was pre - post quasiexperimental group. The participants of the study consisted of 30 students representing one group (one intact class) at first year Al-Shoban Al-Muslemeen secondary school during the academic year 2018/2019. The materials and instruments used included: A checklist of EFL fluency skills required for first year secondary stage students, two EFL fluency tests (used as a pre and post test) and an analytic rubric for scoring them, and a teacher's guide for using e-portfolio. The pre EFL fluency skills test was administered to the participants. The students were taught using e-portfolio to develop their fluency skills. Then, the posttest was administered. A quantitative data analysis was conducted; t-test was used to compare the means scores of the pre-test and the post-test of the study participants. Results showed that the participants' EFL fluency skills developed significantly as a result of using e-portfolio. Therefore, it can be concluded that using e-portfolio was effective in developing EFL first year secondary stage students' fluency skills.

Keywords: EFL fluency skills, portfolio, electronic portfolio. 


\section{استخدام ملف الإنجاز الإلكتروني لتنمية مهارات الطلاقة بالالغة

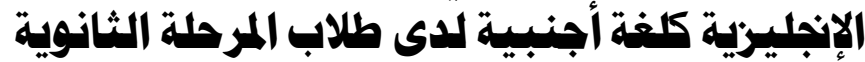

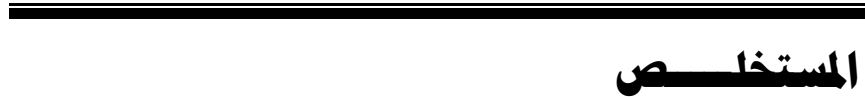

يهدف البحث الحالي الى التحقق من مدى فاعلية استخدام ملف الإنجاز الإلكتروني

لتتميـة مهـارات الطلاقـة باللغــة الإنجليزيـة كلغـة أجنبيـة لـدى طـلاب الصـف الأول الثـانوي. استخدمت الباحثة التصميم الثبه التجريبي للقياس القبل -البعدي مجموعة تجربيية. وتكونت عينـة الدراسـة مـن ثلاثون طالبة (فصـل 1-1) مـن طـلاب الصـف الأول الثانوي مـن مدرســة

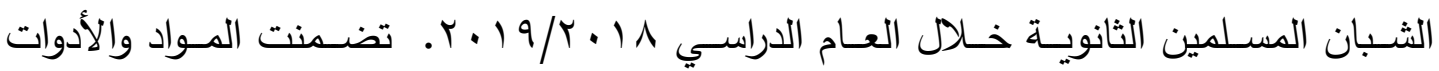
المستخدمة: قائكـة لمهارات الطلاقة في اللغـة الإنجليزيـة كلغـة أجنبية المطلوبـة لطلاب الصف الأول الثانوي، واختبـارين للطلاقـة في اللغـة الإنجليزيـة كلغـة أجنبيـة (يستخدم كاختبـار قبلي اختبار بعدي) ومقياس للتصحيح الاختبارات ودليل المعلم لاستخدام ملف الإنجاز الإلكتروني.

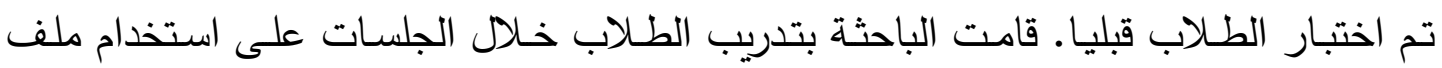
الإنجاز الإككتروني لتنمية مهارات الطلاقة لديهه. تم اختبار الطلاب بعديا ثم تم إجراء تحليل كمي للبيانـات؛ واسـتخدام اختبـار (ت) لمقارنـة الـدرجات القياسـية للاختبـار القبلـي والاختبـار البعدي للمشاركين في الدراسة. وقد أسفرت النتائج أن مهارات الطلاقة لدى طلاب الصف الأول الثانوي في اللغة الإنجليزية كلغة أجنبية قد تطورت بشكل ملحوظ نتيجة استخدام ملف الإنجاز الإككتروني. للأك، يمكن أن نستنتج أن استخدام ملف الإنجاز الإكتروني كان فعالا في تطوير مهارات الطلاقة لطلاب الصف الأول الثانوي في اللغة الإنجليزية كلغة أجنبية.

الكلمـــات المفتــاحيــــة :مهارات الطلاقة باللغة الإنجليزيـة كلغة أجنبية-ملف الإنجاز - ملف

$$
\text { الإنجاز الإلكتروني. }
$$




\section{Introduction and Review of Literature:}

Language has a vital role in the human communication. It is not only a means of communicating thoughts and ideas, but it builds relationships and cultural ties as well. English is one of the most dominating languages in the world; thus, people learn to speak English to get access to a broader range of information, connections, and opportunities.

Speaking is one of the four language skills (reading, writing, listening and speaking). It is one of the major skills that should be mastered by learners to learn English. Speaking is accepted as an important skill for communication. The success of learning a language can be evaluated on the basis of the development in the learners' speaking performance (Goh\& Burns, 2012). Chaney and Burk (1998) defined speaking as the process of building and sharing meaning through the use of verbal and non-verbal symbols, in a variety of contexts. Speaking is a process of constructing and interacting with meaning that involves receiving, producing and processing information (Florez, 1999). Moreover, Bailey (2007) stated that speaking is producing orderly meaningful words to convey a specific meaning since it is a human behavior that is usually analyzed. Bygate (2010) illustrated that speaking a language requires not only to know a certain amount of vocabulary and grammar structures but also knowing how to adjust them to the circumstances and implement them smoothly.

\section{Speaking Skills}

It is important to help learners to put words together to produce meaningful, suitable and clear speech. Improving learners speaking skills can help leaners to master a language not only grammatically but also phonologically (Romero, 2014). Therefore, it is necessary to identify which skills or features need to be developed. According to Brown (2001) there are various speaking skills that should be developed to master speaking such as conversational discourse, pronunciation skills, accuracy and fluency skills and interaction skills. 


\section{Conversational discourse}

indicates the ability to achieve pragmatic goals through interactive discourse with other speakers. Pronunciation is a key to achieve full communicative competence. The most relevant features of pronunciation are given high priority by the top-down approach which stresses the attention to larger chunks of pronunciation such as stress, rhythm and intonation rather than building learner's articulatory competence such as mastering some phonemes and allophones which are related to the bottom up approach. Accuracy and Fluency are vital goals in language teaching. Accuracy can be achieved by concentrating on some elements of phonology, grammar and discourse. On the other hand, fluency may be an initial goal in language teaching. Interaction is one of the biggest difficulties facing speakers. Learners should be engaged in a process of negotiation of meaning rather than the multiplicity of words, phrases, sounds and discourse forms.

Burns (2012) illustrated that mastering speaking involves developing certain components to produce appropriate suitable spoken language to be engaged in specific social situations. Speaking skills include: knowledge of language and discourse, Core speaking skills and Communication strategies.

\section{Knowledge of language and discourse}

involves the knowledge of vocabulary and grammar structures, the clear pronunciation and the organization of the speech to be socially and pragmatically appropriate. Core speaking skills include the ability to produce fluent and quick language (such as: Pausing, chunking, discourse markers, formulaic language) and the engagement in a process of meaning negotiation (such as: initiating topics, turn-taking, intentions, opening/closing conversations). On the other hand, Communication strategies indicate the action of developing cognitive strategies, (such as: paraphrasing, gestures, word coinage and approximation), metacognitive strategies (such as: planning what to say, how to say something), and interaction strategies (such as: asking for clarification/repetition, reformulating, rephrasing, and checking comprehension). 


\section{Fluency skills}

Fluency refers to the ability to speak fluently, confidently and at a relevant rate (Bailey, 2007). According to Goh (2007) fluency depends on a combination of abilities: a reasonable command of grammar, using appropriate vocabulary, and clear pronunciation. Nation and Newton (2009) indicated that the extended nature of fluency is not only the planning and delivery of speech but it is also the comprehension of speech. Moreover Nation and Newton described the following characteristics of fluency:

- Fluent learners can take part in meaning-focused activity and do it speedily and easily without disrupting the flow of talk.

- Fluent learners do not need a great deal of attention and effort.

- Fluency is a skill that depends on the language knowledge and can be developed through restructuring of knowledge and making use of what is already known.

Boonkit (2010) mentioned that various elements can affect the learners' speaking fluency skills such as listening skills, sociocultural factors, affective factors, and other linguistic and sociolinguistic competence such as grammatical, discourse, and strategic competence. EFL learners should understand words and sentences; they also have to understand how words are divided into various sounds, and how sentences are stressed in specific ways. Speakers should use accurate structures and vocabulary which contributes to their fluency. Moreover, speaking fluency involves the ability to produce the spoken language without undue pausing or hesitation (Derakhshan\& Beheshti, 2016). Additionally, fluency can be associated with knowledge and use of multiword expressions (Thomson, 2017).

Nation and Newton (2009) indicated that teaching speaking demands various activities, facilities, techniques and real opportunities to interact with the target language. According to Shumin (2002), the difficulty of learning speaking as a foreign language results from the requirement of 
interacting suitably in social situations. Burns (2012) illustrated several important factors about which teachers should think carefully to be able to guide learners to speak naturally and smoothly They include: using a wide range of core speaking skills, developing fluency in expression of meaning, using grammar flexibly to produce a wide range of utterances that can express meaning precisely and using suitable vocabulary and accurate language forms closely connected to their speaking needs.

Wang (2014) suggested a four-step model for teaching speaking. Pre-speaking activities, while speaking Activities, Post Speaking Activities and Extension Practice. In Pre-speaking activities, learners are supported with language knowledge as well as enough time to think and plan about language. Various activities could be concluded such as pretask planning, pre-speaking support and authentic input. In the pre-task planning, learners are given enough time to plan what to say and how to say it. In the pre-speaking support: learners are provided with some related vocabulary and background information that can help learners to generate ideas. In authentic input it is essential to present some DVDs to offer an example and can transfer learners from "input" to "output".

In the while speaking activities, the meaning is focused during the task and form of the language can be focused on afterwards. Some activities could be included, such as speaking tasks, using a fluency technique and forming automaticity. There are three tasks that can develop fluency, such as information gap task, problem solving tasks and social monologue. Forming automaticity and recalling large amount of vocabulary reduce the time and increase fluency.

Post speaking activities include activities such as language focused activities, self-repairs and corrective feedback that can be used to emphasize the learners' accuracy. Language focused activities can improve learners' accuracy through three stages noticing, comparing and integrating. Self-repairs activities can help learners to focus on the correct use of language. Corrective feedback activities can help teachers to provide learners with valuable feedbacks by recording learners' performances that help the teachers to listen to these records one by one and provides corrective feedbacks individually. 


\section{Extension Practice:}

Tasks repetition is useful to develop learners' fluency and accuracy as repeating the same tasks or parts of the task can reduce the cognitive load, help learners to produce fewer errors and help them to develop their fluency. Repeating tasks inspire comfortable zones for learners and help them to store new information.

In brief, special attention and instruction should be paid to help learners to speak. Moreover, learners need a lot of opportunities to practice due to low exposure to the target language and contact with natives. Consequently, teachers should develop authentic activities, real life situations, and meaningful tasks that promote creating an encouraging and motivating classroom environment. Such environment helps students to speak accurately and fluently

\section{E-portfolio}

Recently, many transitions have been driven to the learning/teaching process. These transitions focus on turning from the teacher-centered to the learner-centered approach where learners become the main actor and figure of the learning process. Due to the terrible development in the world of technology, the implementation of various technology based methods in teaching became a must. One of these new tools is portfolio which supports learner-centered approach. Portfolio focuses on understanding students' ways of knowing what they know. Moreover, it is a means for the transformation of learning systems and deep learning (Watson et al, 2016).

Fong, et al (2014) indicated that constructivism emphasized the importance of individuals' needs and the role of learners' backgrounds to build their personal experience. Shifting away from teacher-centered to knowledge-centered and learner-centered approaches helped the emergence of this theory (Kaufman, 2004). Thus, constructivism is a theory about how people learn. A social dimension was added to constructivism by Vygotsky 
(1978) which became known as socio-constructivism. This perspective led to the active engagement of learners that stresses the various paths of discovery, concept acquisition, and external and internal scaffolding. These perspectives provide learners with unlimited opportunities to be engaged in hands on, minds on identifying new patterns, acquiring new concepts and constructing new understandings (Kaufman, 2004). Consequently, the assessment have been affected by these changes and shifts in the roles of the learners and teachers. Therefore the terms of alternative assessment and authentic assessment are increasingly used. Therefore, portfolio development and assessment are in alignment with these current learning theories in regard to the variety in pace, learning styles, and cognitive development of students (Anderson, 1998;Baron \& Boschee, 1995; Yurdabakan, 2011). E-portfolios can also function as a formative, criteriareferenced, and authentic form of assessment (Lorenzo \& Ittelson, 2005; Dorninger \& Schrack, 2007; Reese \& Levy, 2009\& Barrett, 2010).

Due to the successive developments in technology, it became possible to digitalize the portfolios and convert them from such insensible folders to electronic media. One of the e-learning tools and technology is e-portfolio. Barrett (2000, P.2) defined the electronic portfolios as "a digital container (that is) capable of storing visual and auditory content including text, images, video, and sound". Challis $(2005$, p.5) provided a deep definition for e-portfolio: "an e-portfolio is described as a selective and structured collection of information, gathered for specific purposes, showing/evidencing one's accomplishments and growth which are stored digitally and managed by appropriate software, developed by using appropriate multimedia and customarily within a web environment and retrieved from a website, or delivered by CD-ROM or by DVD". In addition, Nguyen (2013) stated that e-portfolio is an online space for students to share and reflect upon learning artifacts and academic experiences. From all previous definitions, it can be concluded that an eportfolio is a digital container that contains learners' authentic evidences for their learning and achievements over time and provides a tool to measure learners' outcomes. 
Lorenzo and Ittelson (2005) emphasized that e-portfolio can enhance teaching, learning and also the assessment process, support student advisement and the preparation of careers, share teaching philosophy and practices, develop department and program self-studies, enhance student qualification documents, and support accreditation process for programs and institution. Moreover, e-portfolio has the power to offer many advantages of accessibility and portability of artifacts, advisor assessments, as well as reflections. Besides, the fundamental point is that the formats of the artifacts such as video and sound recordings are difficult to be included in a traditional portfolio but by contrast they are easily included in an e-portfolio. Finally, the software packages of many e-portfolios can permit students to control who is able to view each artifact.

E-portfolio can help to facilitate and document the learning experience. Reese and Levy (2009) pinpointed that e-portfolio has the power to archive students work, blend information literacy, technology fluency, and domain knowledge, teach portable skills, engage students critically, treat students as thinkers, and support the new era of accountability. Yastibas and Yastibas (2015) emphasized that e-portfolio can be used effectively and efficiently in teaching, learning, and assessment as it is learner-centered. It can put the responsibility of the process of learning on the students themselves by enabling them to organize and control the content of their e-portfolios, which helps them to personalize their e-portfolios. This responsibility requires students to reflect and assess their own learning.

Wade, Abrami and Sclater (2005) concluded five stages to developing an e-portfolio: (1) collection, (2) selection, (3) reflection, (4) evaluation and (5) celebration. In the collection stage, teachers and students work together to save artefacts that represent successes and opportunities for growth. In the selection stage, teachers and students review and evaluate the saved artefacts and jointly decide which of those 
artefacts best demonstrate the achievement of learning goals. At the reflection stage, students articulate their thinking about each piece in the portfolio. Students evaluate their own growth over time as well as discover any gaps in their development. This stage is undoubtedly the most crucial and it is what enables portfolios to become lifelong learning tools. In the evaluation stage students compare their reflections to their pre-set goals and other achievement standards and indicators and set learning goals for the future. Finally, in the celebration stage, students share their portfolios with their peers.

Baris and Toson (2013) stated that e-portfolio can be integrated and developed through four stages: (1) Identifying e-portfolio target (2) Determining subjects and content of e-portfolio (3) Use of e-portfolio (4) Presentation of e-portfolio. Identifying e-portfolio target: this stage includes determining the design, the reason of using e-portfolio and the audiences of the e-portfolio. Determining subjects and content of e-portfolio: the platform and the interface of the e-portfolio will be determined. Moreover, the shared items will be selected and the access level will be determined. Use of e-portfolio: in this stage the format of the content will be included. The issues such as the environment of e-portfolio, where it will be used, and the use of social network will be determined. Presentation of $e$ portfolio: in this stage some issues will be determined such as how eportfolio platform and downloading data will be saved and presented.

To sum up, there are five steps to develop an e-portfolio. (1) Identifying the aim and goal of the e-portfolio. (2) Selecting the artifacts that document the learners' growth. (3) Reflecting on each piece in the eportfolio. (4) Evaluating the learners' work by themselves. (5) Presenting and sharing the e-portfolio.

There are various studies conducted to investigate the effect of using e-portfolio within the learning/teaching process. Most of these previous studies concerning the use of e-portfolio focused their attention on the development or assessment of students' writing skills such as: Ahmed (2010); Erice and Ertas (2011); Nicolaidou (2013); Abd-Allah (2016); Azarfam (2016) and Esfandiari and Meihami (2017). 
Ahmed (2010) conducted a study to investigate the effect of using electronic portfolios on student teacher's writing performance, reflective thinking, and writing apprehension. Participants of the study were $30 \mathrm{EFL}$ student teachers, at the faculty of education at Suez and they were exposed to four instruments: two writing performance tests, a reflective thinking test, and a writing apprehension scale. It was concluded that electronic portfolios had a significant effect on the writing performance and reflective thinking, but not on the writing apprehension of EFL student teachers.

Erice and Ertas (2011) explored the effect of using e-portfolio on developing the writing skills of English language learners at the preintermediate language proficiency level. The study investigated using portfolio through online writing practice compared with paper-based practice in terms of achievement. The results indicated that the digital environment enhanced the language writing skills and e-portfolio can be used in developing foreign language teaching curricula.

Nicolaidou (2013) conducted a study to investigate the effect of using e-portfolio to enhance students' writing performance and facilitate feedback. Results showed that there were learning gains with respect to students' writing performance over time. Moreover, a qualitative analysis of students' comments showed that students provided more thorough peer feedback over time and became gradually more able to provide more corrective feedback.

Abd-Allah (2016) investigated the effectiveness of using electronic portfolio for developing EFL critical writing skills among second grade preparatory students $(n=60)$. Results revealed that using electronic portfolio was effective in enhancing critical writing skills among the experimental group members.

Azarfam (2016) investigated the effectiveness of an e-portfolio based writing method using analytic traits on writing performance of Iranian university students in a public Malaysian university. The results showed that the electronic environment of the e-portfolio played a significant role in developing the writing performance of the learners. 
Esfandiari and Meihami (2017) explored the effects of supplying Iranian EFL learners $(n=60)$ with direct corrective feedback across levels of language proficiency via e-portfolio. The findings showed significant differences for two components of writing; content and mechanics. The results confirmed the efficacy of e-portfolio as an online platform to deliver direct feedback to language learners, helping language teachers to use it as a useful mode of feedback delivery across levels of language proficiency.

On the other hand, some studies were concerned with the use of eportfolio for developing or assessing students' oral performance skills and speaking fluency skills such as Yoshida (2001); Huang and Hung (2010); Cepik and Yastibas (2013); Safar and Koosha (2016); and Laoun and Khampusaen (2018.

Yoshida (2001) conducted a study to examine the effect of using oral portfolio on the authentic progress assessment of oral language. The findings indicated that oral portfolio helped the learners to be more selfdirected and self-starting by motivating them to take more responsibility for their own learning. The study concluded that oral portfolio can be used as an assessment tool for assessing students' speaking skills which is not being done satisfactorily in the Japanese classrooms and at the same time it can be used as a tool for raising self-regulated learning.

Huang and Hung (2010) examined the effect of using e-portfolio to develop oral performance in EFL conversation classes. 30 participants were selected. The results revealed that using e-portfolio enhanced the learners' oral performance in terms of total words and lexical richness but not in syntactic complexity. The study concluded that e-portfolio developed learners' oral performance lexically but not syntactically.

Cepik and Yastibas (2013) conducted a study to investigate whether electronic portfolios has the similar positive effect on improving speaking skills as it does on writing skills. There were seventeen participants, they were students in an English Language preparation department of one of the universities in Turkey. The results showed that using e-portfolio is effective in developing EFL speaking skills and this is generally noticed in learners' use of language (grammar, pronunciation, and vocabulary) 
Safar and Koosha (2016) used speaking portfolio as an alternative form of assessment for assessing Iranian EFL learners' speaking ability at the intermediate and advanced proficiency levels. 72 participant were selected to participate in the study. The results showed that the experimental groups using speaking portfolio performed better than the control groups in terms of speaking ability.

Lao-un and Khampusaen (2018) investigated the effect of using eportfolio to promote English speaking ability of Thi EFL undergraduate students. Also, the students' opinions towards using of e-portfolio to enhance their speaking ability were investigated. The study followed the qualitative examinations. The results revealed that using e-portfolio enhanced the students' English speaking ability. Moreover, the results reported that e-portfolio became a good and useful additional practice tool to help students to enhance their speaking ability in terms of accuracy, fluency, and pronunciation respectively. From all the previous studies, it can be concluded that using e-portfolio is increasingly demanded worldwide. Using an e-portfolio within the educational process needs more investigation about its nature and implementation. Specifically, in Egypt there are no studies indicating the effect of using e-portfolio to develop speaking skills and whether it has positive benefits on the student's speaking performance.

\section{Context and statement of the problem}

The problem of this present study can be identified in the first year secondary school students' poor mastery of the needed EFL speaking skills that should be developed at this stage. This can be due to the predominant traditional methods of teaching speaking. Moreover, students rarely have real opportunities to practice the language. Therefore, students at the secondary stage can't be even engaged in short conversations and can't use the language in real life situations.

To make sure of the study problem, a pilot study was conducted on 20 students of first year secondary stage students at El-shoban El- 
Muslimeen Private Schools, Benha Educational Administration, ElQualubia Governorate during the second semester of the academic year 2018-2019. The researcher used the EFL fluency skills test prepared by Amin (2007). The results of the test showed that there is a lack in students' fluency skills. It can be concluded that students lack the skills to convey the meaning and interact in social situations. Moreover students needed to be motivated to enhance and develop their fluency skills.

The problem of the study was more advocated by the results of previous related studies in the Egyptian context such as the studies of ElKhuli (2000); Torky (2006); Amin (2007); Mohammed (2011); Gad (2012); Mosleh (2016); Farag (2017); and Gad (2018). These studies stressed that the EFL fluency skills were neglected in the Egyptian secondary schools. This may be attributed to various factors such as the overcrowded classes that has made teaching fluency skills extremely difficult, the increased emphasis on the grammatical structures, and the limited assessment system in Egypt. This led the previous studies to shed the light on the importance of using new effective strategies in teaching fluency skills at the classes to foster and enhance the students' performance.

\section{Questions of the study}

1- What are the EFL fluency skills required for first-year secondary school students?

2- What are the features of electronic portfolios for developing EFL fluency skills among first-year secondary school students?

3- What is the effect of using e-portfolio on developing EFL fluency skills among first-year secondary school students?

\section{Hypotheses of the study}

The research hypotheses have been formulated as "There is a statistically significant difference between the mean scores of the study participants in the pre and post assessment of the EFL fluency skills in favor of the post assessment". 


\section{Research Method}

This part of the research is to illustrate the research methodology that has been followed to investigate the effectiveness of using eportfolio to develop EFL fluency skills among first year secondary stage students. The methodology includes the following:

1- Participants of the study.

2- Research design.

3- Instruments and materials of the study.

\section{Participants of the study}

The participants of the present study consisted of first year secondary school students at El-shoban El-Muslimeen Schools, Benha Educational Administration, El-Qualubia Governorate. Thirty students $(n=30)$ participated in the study during the academic year 2018/2019.

\section{Research design}

The present research is a quantitative research. The quasiexperimental one group design was used to investigate the effectiveness of using e-portfolio to develop fluency skills among first year secondary school students at El-shoban El-Muslimeen Schools.

\section{Instruments and materials of the study}

To achieve the purpose of this study, the following instruments and materials were prepared:

a) A checklist of EFL fluency skills required for first year secondary stage students.

b) Two EFL fluency tests (used as a pre and post test) and an analytic rubric for scoring them.

c) A teacher's guide to describe the steps to be followed when using e-portfolio to develop some EFL fluency skills.

\section{A) The Checklist of EFL fluency Skills}

The main aim of developing the checklist of EFL fluency skills is to determine the EFL fluency skills required for the first year secondary 
school students. The initial form of the checklist of EFL fluency skills included four sub skills. To validate the checklist of EFL fluency skills, it was submitted to jury members specialized in EFL curricula and methods of teaching $(\mathrm{N}=11)$ and English language supervisors $(\mathrm{N}=4)$ to identify the most suitable skills for the secondary stage students. The checklist of EFL fluency skills was modified according to the jury members' opinions.

\section{B) The pre and post EFL fluency skills Tests}

A pre and a post EFL fluency skills tests were prepared to investigate the effectiveness of using e-portfolio to develop the EFL fluency skills among first year secondary school students

\section{Description of the EFL fluency skills tests}

The test consisted of two items. These items measured the students' ability to speak naturally, respond spontaneously, and to speak with acceptable accent. The first item, students were asked to prepare their ideas and answer some questions to discuss certain topic. The second item, students were asked to describe given pictures and speak about it without repetition.

\section{Piloting the Test}

The EFL fluency test was piloted on 26 first year secondary stage students, other than those participants in the study, at Al-shoban AlMuslemeen secondary school in Benha Educational Zone, on the 24 th of February, 2019. The results revealed that the instructions and items of the test were clear. In addition, the topics were interesting and suitable for students.

\section{Validity of the EFL fluency skills tests}

\section{Face Validity}

To estimate the validity of the EFL speaking skills tests the first version of the test was submitted to a panel of faculty staff members specialized in EFL curricula and methods of teaching $(\mathrm{N}=11)$ and English language supervisors $(\mathrm{N}=4)$ to check the test items concerning 
the appropriateness of the test items for first year secondary stage students, sufficiency of the time and clarity of the test guidelines and items and suitability of the test for the students' language level. The tests were modified according to the jury members' opinions.

\section{Internal Consistency}

Pearson correlation coefficient between each item of the test and the total score was calculated to estimate internal consistency. Table (1) presents these correlations.

Table 1. Pearson correlations between the scores

of the test items and the total score of the test

\begin{tabular}{|c|c|c|c|}
\hline \hline \multirow{4}{*}{$\begin{array}{c}\text { Fluency } \\
\text { skills }\end{array}$} & Item No. & Correlation & Level of significance \\
\cline { 2 - 4 } & 1 & .626 & .01 \\
\cline { 2 - 4 } & 2 & .780 & .01 \\
\cline { 2 - 4 } & 3 & .715 & .01 \\
\hline \hline
\end{tabular}

Table (1) shows that the correlation coefficients between the test items and the total scores are significant at 0.01 level which indicates that the test is valid.

\section{- Reliability of the EFL speaking skills tests}

Statistical Package for Social Sciences (SPSS) program (version 18) Cronbach's alpha and Inter-rater reliability were used to estimate the EFL fluency test reliability. Using Cronbach's alpha formula, the reliability coefficient of the test was (.898). This showed a high test reliability. The EFL speaking skills test was corrected by two raters. The first rater was the present study researcher while the second was another researcher, a language instructor, at Benha Faculty of Education. Using Pearson correlation coefficient, the correlation coefficient between the estimation of the two raters was (.983) which is significant at the (0.01) level. 


\section{Rubric of the EfL fluency Skills Tests}

To score the participants' EFL fluency skills, an analytic rubric was prepared and used to ensure the objectivity and the transparency of scoring the test. It is scored on a four points Likert scale ranging from " 4 " to " 1 " where "4" refers to the highest performance level, while " 1 " indicates the lowest performance. The rubric was submitted to a panel of faculty staff members specialized in EFL curricula and methods of teaching $(\mathrm{N}=11)$ and English language supervisors $(\mathrm{N}=4)$ to validate the rubric. The jury members indicated that the items are clear and accurate.

\section{A) The Teacher's Guide}

The researcher prepared a teacher's guide that describes in detail how to use e-portfolio to develop EFL fluency skills for first year secondary stage students. Nine sessions were prepared. They lasted for three weeks with three sessions per week and the duration of each session was about 90 minutes. The first session was an introductory and orientation session and the rest of the sessions were for developing and consolidating the EFL fluency skills.

\section{Teaching using the e-portfolio}

Teaching using e-portfolio went through four stages according to Wang's (2014) model: The Pre-speaking stage, the while speaking stage, the post speaking stage and the extension speaking stage. At the pre speaking stage, students were trained to create and use e-portfolio during the orientation session then, they created their e-portfolios. The educational audios or videos related to the topic of the session were played to give the students an input. Students had enough time to prepare to speak and to identify the ideas needed to be expressed. The researcher guided students to brainstorm ideas and helped students to predict what language would be needed.

During the while speaking stage, students were assigned to individual, pair or group work tasks. The researcher monitored and helped students to formulate their speech, then students began to draft, redraft, 
and rehearse what they were going to say. Students performed the tasks in front of the class and the performances were recorded. At the post speaking stage, students uploaded their performances on their e-portfolio

The researcher asked students to self-assess their performances and to assess their peers using the rubric. The performances were also evaluated by the researcher at the end of each session. At the extension practice stage, students were asked to repeat these tasks again and to self-assess their performances again. The researcher gave introspective assessment on the basis of the rubric.

\section{Findings of the study}

In the light of the study hypothesis, the findings of the present study are presented. The Statistical Package for Social Sciences (SPSS) program (version 18) and paired samples t-test were used to analyze the data of the present study. The findings are showed as follows:

Table (1) included the participants' mean scores, standard deviations (S.D), t-value, and level of significance in the pre-post assessment of the EFL fluency skills.

Table 1. Findings of the $t$ - test between the mean scores of the study participants in the pre-post assessment of the EFL fluency skills

\begin{tabular}{|c|c|c|c|c|c|c|c|}
\hline \hline $\begin{array}{c}\text { EFL Speaking } \\
\text { micro skills }\end{array}$ & Measurement & N. & Mean & S.D & Df. & t-value & Sig. \\
\hline \multirow{2}{*}{ Fluency } & Pre-test & \multirow{2}{*}{30} & 5.933 & .917 & & & \\
\cline { 2 - 5 } & Post-test & & 8.067 & .828 & & 17.147 & .01 \\
\hline \hline
\end{tabular}

Table (1) indicates that there is a statistically significant difference between the mean scores of the study participants in the pre and post assessment of the EFL fluency skills in favor of the post assessment, where the $t$-value is (17.147) which is significant at the (0.01) level of significance. Consequently, the hypothesis was supported. This difference is illustrated by the following figure. 


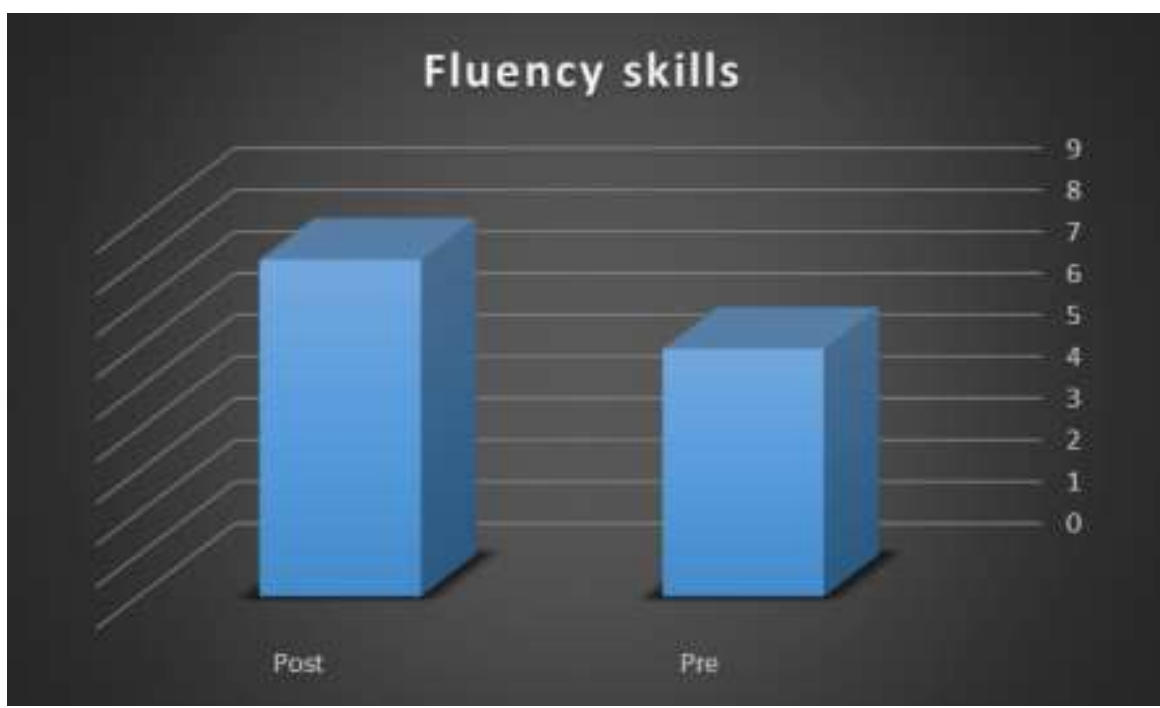

Figure 1. The mean scores of the study participants in the pre-post assessment of the fluency skills.

\section{Discussion of the findings}

The aim of this study was to develop EFL speaking fluency skills among the first year secondary stage students using e-portfolio. The effectiveness of using e-portfolio within the context of speaking skills was examined since relatively few studies had examined this facet. The implementation of the e-portfolio was through eight sessions in addition to an orientation session. These sessions dealt with the speaking fluency skills and provided students with real opportunities to practice the language via different tasks. After the implementation of the e-portfolio the results were positive and promising since they showed that using eportfolio was effective in developing EFL speaking fluency skills. More than one factor contributed to these results. Firstly, due to the stunning effect of technology in the teaching- learning process, students were encouraged and interested in completing their tasks. In addition, using technology increased student engagement and motivation; and accelerated their learning. Secondly, the nature of e-portfolio itself had its effect on the students' speaking fluency skills.

There were two kinds of e-portfolio. A teacher's e-portfolio and students' e-portfolios were developed. The teacher's e-portfolio was 
developed by the researcher and shared with the students. The teacher's e-portfolio documented the teaching materials, audios, videos, selfassessment sheets, and the rubric. The researcher uploaded videos and audios to provide students with an accurate representations of native speakers. Moreover, the teacher uploaded the assignments, the selfassessment sheets and the rubric for students. Using the teacher's eportfolio enabled the teacher to send feedback on the students' performances in the form of comments, as opposed to marks. In addition, it enabled the teacher to transfer the passive information to dynamic, flexible and growing, and can be shared, searched and gained at any time inside and outside the classroom.

Students developed their e-portfolios by themselves to demonstrate their learning process instead of having final results. Students became able to review their work in the light of the received feedback and to selfassess themselves and their peers'. The use of e-portfolio allowed students to take increasing responsibility for their own learning by recording and reflecting on their learning in their e-portfolios.

Using e-portfolio presented various learning styles that helped students to obtain their learning aims and encouraged learners to be engaged in the learning process. E-portfolio maximized the students' use of the language to complete its requirements such as discussing the topics, communicating with each other and reflecting on their own work and their peers'. Moreover, one of the vital elements is using various methods of assessment: self-assessment, peer-assessment and teacherassessment. Self-assessment and reflecting on their own work helped students to note the strength and weakness points by themselves. Peerassessment involved students in the responsibility for assessing the work of their peers. Students engaged in providing feedback to their peers. Teacher-assessment helped to identify the students' knowledge level, examine their errors, make use of this to direct the next step in teaching and subsequently achieve the ultimate goal of improving their speaking skills; i.e- assessment for learning 
In addition, a vital factor was the various kinds of activities and tasks that were used through e-portfolio. Students were required to role play, use fill in gap activities, discuss topics, describe pictures, express themselves and to give opinions. These activities were interesting, touched their real life and motivated them and in the same time were appropriate for the students' level.

The improvement of the students' fluency skills may also be interpreted as e-portfolio included several educational videos and audios for native speakers that worked as models and they worked as an input for the students then, students transferred these experiences into their own speech. Moreover, recording the performances and asking students to listen to their own performance and to their classmates' performances helped students to polish their skill, take notes and find out their errors and weakness points by themselves. The repetition of the tasks or parts of the tasks and reassessing their performances helped them to enhance and improve their performances. In addition, the opportunities that were provided for students to learn and practice the pre-assembled chunks of language helped them to speak fluently. Also, encouraging students to practice and exercise speeches and discussions before they take place positively affected on the students' performances.

\section{Conclusion}

According to the results of the present study, it can be concluded that using e-portfolio is effective in developing EFL fluency skills among first year secondary students. This positive result can be due to the integration of technology represented in e-portfolio, various activities, rich resources, and using various methods of assessment in the teaching/learning process. Consequently, using e-portfolio is recommended in our classrooms. 


\section{Recommendation for Further Research}

The present study can offer the following recommendation based on its findings:

- Teachers and students should receive advanced training on making use of the benefits of technology.

- E-portfolio should be used in teaching EFL speaking skills at the secondary stage.

- Teachers should pay intensive attention to select various tasks that include different patterns of interaction features.

- Students should be engaged in conversations, dialogues and conversations in a non-threating atmosphere.

- Teachers should be provided with special training on how to choose or design successful speaking activities.

- Self-assessment and peer assessment should be used as they can increase the students' self- confidence, empower their metacognitive abilities and enhance the communication skills.

- The role of the teacher is to work as a motivator, facilitator and organizer.

- Students should be provided with unlimited opportunities to practice language.

- The learning environment should be turned from threat and fear to an enthusiastic environment.

- Turning from teacher-centered to student-centered approach is a fundamental demand to involve students in the learning process.

- The schools' IT infrastructure should have intensive care and attention. 


\section{References}

Abd-Allah, A.A. (2016). Using e-portfolio for developing preparatory stage students' EFL critical writing skills. Unpublished MA Thesis, Faculty of Education, Ain Shams Universit, Egypt.

Adams, D. M., \& Hamm, M. E. (1992). Portfolio assessment and social studies: Collecting, selecting, and reflecting on what is significant. Social Education, 56(2), 103-105.

Ahmed, Z.S. (2010). Using electronic portfolios to develop EFL student teacher's writing performance and reflective thinking and reduce their writing apprehension. Unpublished Doctoral Thesis, Faculty of Education, Suez Canal University, Egypt.

Amin, A.E. (2007). A suggested self-efficacy-based program for developing secondary school students' EFL speaking Skills. Unpublished MA Thesis, Faculty of Education, Benha University, Egypt.

Anderson, R. S. (1998). Why talk about different ways to grade? The shift from traditional assessment to alternative assessment. New directions for Teaching and Learning, 74, 5-16.

Azarfam, A. Y. (2016). Effectiveness of an e-portfolio-based writing method using analytic traits on writing performance of EFL students. Published Doctoral Dissertation. Putra University, Malaysia. Retrieved from http://psasir.upm.edu.my/id/eprint/65672/1/FPP\%202016\%2013\% 20upm\%20ir.pdf

Bailey, K. M. (2007). Practical English language teaching: speaking. New York: McGraw-Hill.

Baris, M. F., \&Tosun, N. (2013).Can social networks and e-portfolio be used together for enhancing learning effects and attitudes? TOJET: The Turkish Online Journal of Educational Technology, 12(2), 51-62. 
Baron, M. A., \& Boschee, F. (1995). Authentic assessment: The key to unlocking student success. New York: Technomic Pub.

Barrett, H. C. (2000). Create your own electronic portfolio. Learning and leading with technology, 27(7), 14-21.

Barrett, H.C. (2010). Balancing the two faces of ePortfolios. Educação, Formação \& Tecnologias, 3(1), 6-14.

Boonkit, K. (2010). Enhancing the development of speaking skills for non-native speakers of English. Procedia-social and Behavioral Sciences, 2(2), 1305-1309.

Brown, H. D. (2001). Teaching by principles: An interactive approach to language teaching. New Jersey: Prentice Hall Regents.

Burns, A. (2012). A holistic approach to teaching speaking in the language classroom. In Linguistic Symposium (pp.165-178), University of Stockholm, Stockholm.

Bygate, M. (2010). Speaking. Oxford: Oxford University Press.

Challis, D. (2005). Towards the mature of eportfolio: Some implications for higher education. Canadian Journal of Learning and Technology,31(3).

Chaney, A. L., \& Burk, T. L. (1998). Teaching Oral Communication in Grades $K-8$. Boston: Allyn and Bacon.

Derakhshan, A., Khalili, A. N., \& Beheshti, F. (2016). Developing EFL learner's speaking ability, accuracy and fluency. English Language and Literature Studies, 6(2), 177-186.

Dorninger, C., \& Schrack, C. (2007). Future learning strategy and ePortfolios in education. International Journal of Emerging Technologies in Learning (IJET), 3(1), 11-14. 
El-Khuli, S. (2000). The Effect of using some questioning strategies in teaching English on developing the first year secondary school students speaking skills. Unpublished MA Thesis, Faculty of Education, Ain Shams University, Egypt

Erice, D., \& Ertas, A. (2011). The impact of e-portfolio on foreign language writing skills. Egitim Bilimleri Fakultesi Dergisi, 44(2), 73-94.

Esfandiari, R., \& Meihami, H. (2017). Impact of Direct Corrective Feedback (DCF) Through Electronic Portfolio (EP) Platform on the components of Iranian EFL Learners' Writing across Levels of Language Proficiency. Journal of Teaching Language Skills, 36(2), 39-74.

Farag, D.Z. (2017). The Effects of an interactive multimedia Program in developing EFL oral communicative skills among secondary school students. Unpublished MA Thesis, Faculty of Education, Minoufiya University, Egypt.

Florez, M. A. C. (1999). Improving adult English language learners' speaking skills .National Center for ESL Literacy Education, ERIC Digest .

Fong, R. W. T., Lee, J. C. K., Chang, C. Y., Zhang, Z., Ngai, A. C. Y., \& Lim, C. P. (2014). Digital teaching portfolio in higher education: Examining colleagues' perceptions to inform implementation strategies. The Internet and Higher Education, 20, 60-68.

Gad, D.A. (2012). The effectiveness of a proposed program based on academic controversy in developing some EFL speaking skills among secondary school students. Unpublished $\mathrm{PhD}$ Thesis, Faculty of Education, Minoufiya University, Egypt.

Gad, D.A. (2018). The effectiveness of a program based on Dogme approach in developing governmental language secondary school students' EFL listening and speaking skills. Unpublished $\mathrm{PhD}$ Thesis, Faculty of Education, Minoufiya University, Egypt 
Goh, C. C. M., Goh, C., \& Burns, A. (2012). Teaching speaking: A holistic approach. New York: Cambridge University Press.

Kaufman, D. (2004). Constructivist issues in language learning and teaching. Annual review of applied linguistics, 24, 303-319.

Lorenzo, G., \& Ittelson, J. (2005). An overview of eportfolios. Educause learning initiative, 1(1), 1-27.

Mohammed, A.F. (2011). Developing some speaking skills in EFL among secondary stage students via multimedia. Unpublished MA Thesis, Faculty of Education, Zagazig University, Egypt.

Mosleh, A.N. (2016). Using some argumentation processes in developing speaking skills of EFL secondary school students.Unpublished MA Thesis, Faculty of Education, Zagazig University, Egypt.

Nation, I. S. P., \& Newton, J. (2009). Teaching ESL/EFL listening and speaking. New York: Routledge Taylor\&Francis.

Nguyen, C. F. (2013). The ePortfolio as a living portal: A medium for student learning, identity, and assessment. International Journal of EPortfolio, 3(2), 135-148.

Nicolaidou, I. (2013). E-portfolios supporting primary students' writing performance and peer feedback. Computers \& Education, 68, 404-415.

Paulson, F. L., Paulson, P. R., \& Meyer, C. A. (1991). What makes a portfolio a portfolio. Educational Leadership, 48(5), 60-64.

Reese, M., \& Levy, R. (2009). Assessing the future: E-portfolio trends, uses, and options in higher education. EDUCAUSE Center for Applied Resear, 1 ,1-12

Romero, B. N. (2014). Improving speaking skills. Encuentro, 18, 86-90. 
Shumin, K. (2002). Teaching Speaking. In J. Richards \& W. Renandya, Methodology in Language Teaching: An Anthology of Current Practice (pp. 204-211). New York: Cambridge University Press.

Thomson, H. (2017). Building speaking fluency with multiword expressions. TESL Canda Journal, 34(3),26-53.

Torky, S. A. (2006). The effectiveness of a task-based instruction program in developing the English language speaking skills of secondary stage students. Unpublished Doctoral Dessertation, Ain Shams University, Women's college, Egypt.

Vygotsky, L. S. (1978). Mind in society: The development of higher psychological processes. USA: Harvard University press.

Wade, A., Abrami, P., \& Sclater, J. (2005). An electronic portfolio to support learning. Canadian Journal of Learning and Technology, 31(3), 1-19.

Wang, Z. (2014). Developing accuracy and fluency in spoken English of Chinese EFL learners. Canadian Center of Science and Education, $7(2), 110-118$.

Watson, C. E., Kuh, G. D., Rhodes, T., Light, T. P., \& Chen, H. L. (2016). E-Portfolios the eleventh high impact practice. International Journal, 6(2), 65-69.

Yastibas, A. E., \& Yastibas, G. C. (2015). The use of e-portfoliobased assessment to develop students' self-regulated learning in English language teaching. Procedia-social and behavioral sciences, 176, 3-13.

Yurdabakan, I. (2011). The view of constructivist theory on assessment: Alternative assessment methods in education. Egitim Bilimleri Fakultesi Dergisi, 44(1), 51. 